\title{
PRODUCT ENGINEERING DAN ANALISIS KELAYAKAN INVESTASI PENGEMBANGAN PRODUK CAIRAN PELAPIS PERMUKAAN AIR PADA KLOSET
}

\author{
Niari Prittu Maypeni, Ade Aisyah Arifna Putri, Ayu Leuditya Fahira, Mega Sri \\ Gunawan, Winda Widya Pangestu, Ratna Purwaningsih*) \\ Departemen Teknik Industri, Fakultas Teknik, Universitas Diponegoro, \\ Jl. Prof. Soedarto, SH, Kampus Undip Tembalang, Semarang, Indonesia 50275
}

(Received: June 19, 2019/ Accepted: August 20, 2019)

\begin{abstract}
Abstrak
Penelitian ini bertujuan untuk melakukan penyusunan konsep produk untuk pembuatan prototype dengan mempertimbangkan suara konsumen (VoC) dan mengukur nilai investasi dari produk cairan pelapis permukaan air pada kloset. Desain produk adalah salah satu tahap yang paling penting dalam memulai suatu usaha menjual produk. Desain produk yang sesuai dengan permintaan konsumen berasal dari kebutuhan konsumen. Oleh karena itu, penelitian product engineering ini menggunakan pendekatan Quality Function Deployment (QFD). Analisis kelayakan investasi dilakukan dengan mencari nilai Net Present Value (NPV), Internal Rate of Return (IRR), Profitability Index (PI) dan Payback Period. Tahap yang dilakukan yaitu penentuan segmentasi pasar dan dilanjutkan dengan penyebaran kuisioner pendahuluan terhadap 24 responsden untuk mengetahui atribut apa saja yang akan muncul sebagai voice of customer. Kemudian tingkat kepentingan konsumen pada atribut kepentingan dikelompokkan menjadi 5 atribut utama, yaitu aroma, desain, portabilitas, efektivitas, dan harga. Hasil pengolahan data menunjukkan atribut desain memiliki hubungan yang paling kuat dengan respons teknis logo dan warna kemasan produk dengan nilai bobot sebesar 42.336. Pengembangan produk diprioritaskan pada respons teknis proporsi/ komposisi bahan baku, kemudian disusul dengan desain logo, warna, dan ukuran kemasan serta jenis bahan baku. Nilai analisis investasi kelayakan dengan metode payback period sebesar 8,63, bulan dan NPV sebesar Rp 10.612.209, IRR sebesar 22,32\% dan PI sebesar 1,75. Hal ini menjadi dasar bahwa investasi layak dilakukan.
\end{abstract}

Kata kunci: Pengembangan Produk; Quality Function Deployment; Analisis Kelayakan Investasi; Desain Produk

\begin{abstract}
[Product Engineering and Feasibility Analysis of Investment of The Development Water Surface Coating Products on Closets] The success of selling a product goes hand-in-hand with the product design on the market. To effectively create a competitive product for the market requires a great deal of product planning, design, and development. In preparing the product development plan will also requires an extended analysis of costs and investment value that will be carried out in the future. This study aims to develop a concept for making a product prototype by considering the consumer's voice (VoC) and measuring the investment value of a coating liquid product for toilet water's surface to minimize the smell of feces. Product design is one of the most important stages in starting a business selling products. Product design in accordance with consumer demand comes from consumer needs. Therefore, the product engineering study uses Quality Function Deployment (QFD) method, whereas the investment feasibility study uses Cost of Goods Sold (CoGS), Profit and Loss Analysis (P\&L), Payback Period (PP), Net Present Value (NPV), Internal Rate of Return (IRR), and Profitability Index (PI). The next step is specifying market segmentation and followed with distributing initial questionnaire to 24 people to determine what kinds of attribute will be selected as a voice of consumer's. Then, all of the attributes will be grouped into 5 customer's requirements characteristics which are scent, design, portability, effectiveness, and price. The design

*Penulis Korespondensi.

E-mail: ratna.tiundip@gmail.com

characteristic has strongest relation with technical response of logo and packaging color
\end{abstract}


with weight value of 42.336. In product development, material proportion is prioritized, followed by logo design, color, product's size, and types of ingredients. The result of investment feasibility study are 8.63 for payback period, Rp 10.612.209,- for projected NPV at $10^{\text {th }}$ period, and $22,32 \%$ IRR. This becomes the the basis of reasoing why investment is feasible.

Keywords: Product Development; Quality Function Deployment; Investment Feasibility Analysis; Product Design

\section{Pendahuluan}

Kesuksesan penjualan suatu produk tidak terlepas dari kesesuaian desain produk yang diluncurkan di pasar dengan kebutuhan konsumen. Desain produk yang baik dapat meningkatkan harga jual dan jumlah penjualan produk. Desain produk dapat didefinisikan sebagai generate idea, pengembangan konsep produk, pengujian produk dan pelaksanaan manufaktur atau jasa (Alexander, 1963). Pengembangan konsep tidak terlepas dari inovasi yang merupakan proses teknologis, manajerial dan sosial ketika gagasan baru pertama kali diperkenalkan dalam suatu kultur (Hartini, 2012). Kotler (2005) mengemukakan tujuh parameter desain produk yaitu ciri-ciri, kinerja, kesesuaian mutu, tahan lama, tahan uji, kemudahan perbaikan, dan model. Aspek sifat fisik berkaitan dengan karakteristik yang mendukung fungsi dasar produk. Aspek kinerja berkaitan dengan tingkat kemampuan produk sesuai fungsinya pada saat beroperasi. Kesesuaian mutu produk merupakan tingkat di mana desain produk mendekati standar sasaran yang direncanakan. Tahan lama berkaitan dengan ukuran waktu operasi atau masa pakai yang diharapkan dari produk. Sedangkan keandalan atau tahan uji berkaitan dengan ukuran kemungkinan suatu produk tidak akan berfungsi salah atau rusak dalam suatu periode tertentu. Aspek kemudahan perbaikan berkaitan dengan ukuran kemudahan perbaikan suatu produk ketika mengalami kerusakan. Aspek model berkaitan dengan gambaran suatu produk tampak dan berkenan bagi konsumen.

Untuk dapat menghasilkan produk yang bersaing di pasar diperlukan serangkaian perencanaan, perancangan dan pengembangan produk (Wignjosoebroto, 2000). Pengembangan produk berkaitan dengan kebutuhan perusahaan untuk mempertahankan keunggulan kompetitif di pasar tempat mereka beroperasi yang menjadi prasyarat untuk kelangsungan hidup dan pertumbuhan perusahaan (White, 1976). Chisnill (1979) menyatakan bahwa perusahaan dengan kemampuan produksi, penelitian dan pengembangan yang kuat perlu menganalisis pasar terlebih dahulu untuk memanfaatkan sumber daya yang mereka miliki. Menurut Ulrich dan Eppinger (2000) proses generic pengembangan produk terbagi menjadi enam fase yaitu perencanaan, pengembangan konsep, perancangan tingkatan sistem, perancangan rinci, pengujian dan perbaikan, dan peluncuran produk. Kundu (2010) membuat sketsa prosedur pengembangan produk dengan mempertimbangkan kondisi nyata dan wawasan konsumen.

Dalam penyusunan rencana pengembangan produk juga diperlukan analisis biaya dan investasi produk. Investasi merupakan unsur vital dalam tahapan perencanaan dan pelaksanaan awal usaha dan pengembangan usaha. Analisis investasi digunakan untuk mengantisipasi kemungkinan terjadinya kegagalan atau kerugian akibat investasi yang akan dilaksanakan (Umar, 2007). Analisis investasi usaha digunakan untuk mengetahui nilai investasi yang akan dilaksanakan di masa mendatang. Penilaian yang dimaksud yaitu menilai apakah usaha yang dijalankan tersebut layak dilaksanakan terutama dari aspek ekonomi dan teknis produksi (Tandelilin, 2010).

Fandri (2005) menggunakan analisis pasar dan analisis keuangan untuk melakukan analisis kelayakan penambahan mesin di perusahaan industri kulit. Gideon (2007) menggunakan analisis sensitifitas dengan tiga skenario yaitu moderat, optimis dan pesimis dalam melakukan analisis kelayakan investasi pengadaan mesin cetak offset separasi. Dede (2007) menggunakan teknik capital budgeting untuk menganalisis kelayakan investasi pada rencana perluasan jaringan. Susanti (2012) melakukan analisis kelayakan investasi perbaikan sarana produksi pada home industry dengan memperhitungkan aspek teknis, keuangan dan produksi. Utomo (2017) menggunakan analisis aliran kas, NPV, PP dan menetapkan batasan kelayakan proyek dalam kajian potensi pengembangan produk transportasi Gyroplane.

Penelitian ini bertujuan untuk melakukan penyusunan konsep untuk pembuatan prototype produk dengan mempertimbangkan suara konsumen (VoC) dan mengukur nilai investasi dari produk cairan pelapis permukaan air pada kloset. Ruang lingkup penelitian ini dilakukan dari tahapan identifikasi kebutuhan konsumen dengan menggunakan koesioner, penentuan atribut produk, penentuan respons teknis dan penyusunan konsep produk. Penelitian product engineering ini menggunakan pendekatan Quality Function Deployment (QFD). Kuesioner disebarkan kepada 24 responsden untuk menentukan atribut utama kepentingan pelanggan yang akan diterjemahkan kedalam respons teknis. Analisis kelayakan investasi dilakukan dengan mencari nilai Net Present Value (NPV), Internal Rate of Return (IRR), Profitability Index (PI) dan Payback Period.

Desain (Perancangan dan Pengembangan) Produk 
Proses pengembangan produk adalah langkahlangkah sistematis atau kegiatan yang digunakan perusahaan untuk menyusun, merancang, dan mengkomersialkan suatu produk (Ulrich \& Eppinger, 2000). Perancangan produk merupakan kegiatan yang penting dilakukan sebelum proses produksi berjalan, karena dalam tahapan perancangan produk akan diperoleh informasi detail dari benda yang akan dibuat (Ginting, 2009). Terdapat enam fase pengembangan produk yaitu perencanaan, pengembangan konsep, perancangan tingkatan sistem, perancangan rinci, pengujian dan perbaikan, dan peluncuran produk (Ulrich \& Eppinger, 2000). Dalam fase 0 yaitu perencanaan, peneliti mengidentifikasi peluang dan segmen pasar. Fase ini juga menentukan apakah produk yang dibuat merupakan produk baru yang tidak pernah ada sebelumnya atau pengembangan dari produk yang sudah ada. Pada fase 1 atau pengembangan konsep, kebutuhan konsumen diidentifikasi dan alternatif konsep produk mulai dikembangkan. Konsep yang dimaksud meliputi bentuk, fungsi dan fitur produk. Fase 2 melakukan perancangan tingkatan sistem meliputi definisi arsitektur produk, dekomposisi produk dan komponen-komponen yang dibutuhkan oleh produk. Pada fase 3 dilakukan perancangan rinci meliputi spesifikasi akhir dari geometris, bahan dan toleransi ukuran setiap komponen produk. Kemudian fase 4 melakukan pengujian dan perbaikan desain dan merupakan tahapan ketika prototype produk mulai dioperasikan untuk menjalankan fungsinya. Pada tahapan ini, perusahaan mengevaluasi berbagai versi fungsi dari produk. Pada fase 5 dilakukan peluncuran produk atau uji coba produksi untuk melatih tenaga kerja dan menyelesaikan masalah yang tersisa dalam proses produksi. Keenam fase dalam pengembangan produk digambarkan pada Gambar 1.

Menurut Ulrich dan Eppinger (2000) kesuksesan pengembangan suatu produk didasarkan pada keuntungan atau profit yang didapatkan dari penjualan produk. Terdapat lima dimensi kesuksesan pengembangan produk, yaitu kualitas produk, biaya produk, waktu pengembangan produk, biaya pengembangan produk, dan kapabilitas pengembangan produk.

\section{Quality Function Deployment (QFD)}

Quality Function Deployment merupakan suatu pendekatan sistematik untuk mengetahui permintaan konsumen dan menerjemahkannya kedalam desain teknis, manufaktur dan perencanaan produksi yang tepat (Kwong \& Bai, 2002). QFD membantu perusahaan atau desainer mendengarkan keinginan konsumen dalam menentukan cara terbaik untuk memenuhi kebutuhan konsumen.

Terdapat empat fase dalam metode QFD, yang meliputi (1) perencanaan produk, (2) pejabaran desain, (3) perencanaan proses dan (4) perencanaan produksi. Fase pertama dimulai dengan penelitian terhadap pasar, pengambilan data-data dari pelanggan dan penyusunan rencana produk baik berupa ide, sketsa ataupun konsep model. Fase kedua yaitu penjabaran desain yang dimulai dengan adanya spesifikasi produk dan komponennya. Kemudian fase ketiga yaitu perencanaan manufaktur di mana proses manufaktur dan peralatan produksi dirancang untuk menghasilkan spesifikasi produk. Fase empat yaitu perencanaan produksi yang bertujuan menghasilkan perencanaan mengenai pengontrolan proses manufaktur dan peralatan produksi untuk membuat produk. QFD menggunakan matrik komrehensif yaitu House of Quality (HOQ) untuk mendokumentasi informasi, persepsi dan keputusan konsumen. Dengan matrik ini, serangkaian kebutuhan pelanggan dapat diterjemahkan menjadi prioritas target teknis yang dibutuhkan untuk memuaskan kebutuhan pelanggan tersebut.

Langkah pengerjaan dalam QFD yaitu dilakukan evaluasi produk, objektif produk, perumusan respons teknis, matriks interaksi antara respons teknis hingga penyusunan konsep. Evaluation Score merupakan penilaian pelanggan dari produk yang sudah ada di pasaran yaitu pewangi ruangan. Target Value merupakan nilai yang diharapkan dari produk yang akan dirancang. Sedangkan objektif produk yang dimaksud yaitu penilaian berupa pembobotan untuk mengetahui atribut yang dianggap paling penting dan diprioritaskan. Perhitungan objektif produk meliputi IR, RII, dan Weight pada Tabel 2. Perhitungan objektif produk dijabarkan sebagai berikut:

1. Importance Rate (IR) diperoleh dari perbandingan antara target value dengan evaluation score.

$$
\mathrm{IR}=\frac{\text { target } \text { value }}{\text { evaluation score }}
$$

2. Relative Important Index (RII) diperoleh dari ratarata penilaian tingkat kepentingan atribut.

3. Weight merupakan perkalian nilai dari IR dan RII.

$$
W=I R x R I I
$$

4. \%Weight merupakan persentase hasil pembobotan tiap atribut.

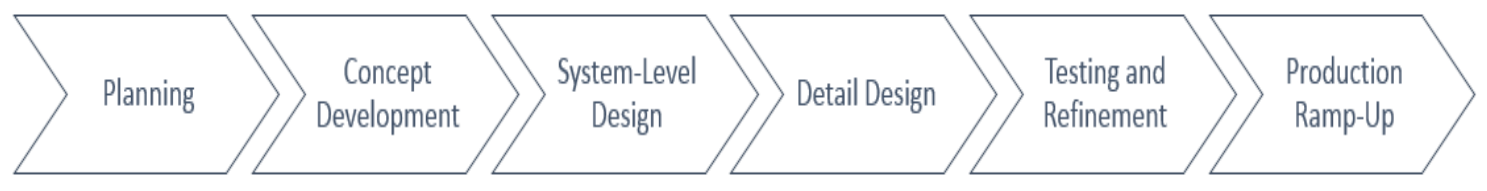

Gambar 1. Fase Pengembangan Produk 
Tabel 1. Atribut Keinginan Konsumen

\begin{tabular}{lc}
\hline \multicolumn{1}{c}{ Atribut Keinginan Konsumer } & Nilai Kepentingan \\
\hline Aroma & 4,33 \\
Desain & 3,92 \\
Portabilitas & 4,17 \\
Efektivitas & 4,54 \\
Harga & 4,5 \\
\hline
\end{tabular}

Tabel 2. Evaluasi Atribut Produk

\begin{tabular}{lcccccc}
\hline \multicolumn{1}{c}{ Dimensi } & Evaluation Score & Target Value & IR & RII & Weight & \%Weight \\
\hline Aroma & 3,55 & 4 & 1,13 & 4,33 & 4,8929 & 15,39 \\
Desain & 3,09 & 4 & 1,29 & 3,92 & 5,0568 & 15,9 \\
Portabilitas & 2,27 & 4 & 1,76 & 4,17 & 7,3392 & 23,08 \\
Efektivitas & 2,36 & 4 & 1,69 & 4,54 & 7,6726 & 24,13 \\
Harga & 2,64 & 4 & 1,52 & 4,5 & 6,84 & 21,51 \\
\hline & & & & & 31,8015 & 100,01 \\
\hline
\end{tabular}

\section{Analisis kelayakan investasi}

Analisis kelayakan investasi usaha digunakan untuk mengetahui keseluruhan modal yang diinvestasikan untuk usaha. Analisis ini digunakan untuk mengantisipasi risiko kegagalan atau kerugian akibat investasi yang dilaksanakan (Umar, 2007). Dalam berinvestasi, perusahaan tidak hanya mendapatkan imbalan investasi tetapi juga risiko yang harus ditanggung akibat hubungan positif antara pendapatan dan risiko. Di mana semakin besar risiko yang harus ditanggung oleh perusahaan maka semakin besar juga pendapatan yang diperoleh. Untuk mengantisipasi risiko, maka diperlukan analisis kelayakan investasi yang disesuaikan dengan risiko yang ada. Analisis kelayakan investasi merupakan penelitian terhadap rencana bisnis yang tidak hanya menganalisis layak atau tidak layak bisnis dibangun, tetapi juga pada saat dioperasikan secara rutin dalam rangka pencapaian keuntungan yang maksimal untuk waktu yang ditentukan (Umar, 2005). Kasmir dan Jakfar (2012) menyatakan bahwa analisis kelayakan investasi adalah kegiatan yang mempelajari secara mendalam tentang suatu kegiatan, usaha dan bisnis yang dijalankan. Sedangkan Husnan dan Suwarsono (2008) menyatakan bahwa analisis kelayakan investasi merupakan penelitian tentang dapat atau tidaknya suatu proyek investasi dilaksanakan dengan berhasil. Dapat disimpulkan bahwa analisis kelayakan investasi merupakan pendekatan yang digunakan untuk mengetahui apakah suatu proyek layak dan menguntungkan atau tidak untuk dilaksanakan.

Terdapat tiga metode yang dapat digunakan untuk penilaian investasi yaitu (Umar, 2007):

\section{Payback Period (PP)}

Metode ini digunakan untuk mengukur suatu periode yang diperlukan untuk menutup kembali pengeluaran investasi dengan menggunakan aliran kas.

$$
\mathrm{PP}=\frac{\text { Nilai Investasi }}{\text { Kas masuk bersih }} \times 12 \text { bulan }
$$

\section{Net Present Value (NPV)}

Metode ini merupakan selisih antara nilai investasi saat ini dengan dengan nilai sekarang dari keuntungan bersih dimasa datang.

$$
\mathrm{NPV}=\sum_{t=1}^{n} \frac{C F t}{1+K^{t}}-I_{0}
$$

Keterangan:

$C F t=$ Aliran kas pertahun pada periode $\mathrm{t}$

$I_{0}=$ investasi awal pada tahun 0

$\mathrm{K}=$ suku bunga

\section{Internal Rate of Return (IRR)}

Metode ini digunakan untuk mencari tingkat bunga yang menyamakan nilai sekarang dan arus kas yang diharapkan di masa datang, atau penerimaan kas dengan pengeluaran investasi awal.

$$
I_{0}=\sum_{t=1}^{n} \frac{C F t}{(1+I R R)^{t}}
$$

Keterangan:

$\mathrm{t}=$ tahun $\mathrm{ke}$

$\mathrm{n}=$ jumlah tahun

$I_{0}=$ nilai investasi awal

$\mathrm{CF}=$ arus kas bersih

$\mathrm{IRR}=$ tingkat bunga yang dicari harganya

\section{Profitability Index (PI)}

Metode ini menghitung perbandingan antara nilai laba bersih dimasa datang dengan nilai investasi saat ini. PI harus lebih besar dari 1 baru dikatakan layak. Semakin besar PI, investasi semakin layak.

\section{Metode Penelitian}

Penelitian ini bertujuan untuk menyusun konsep pengembangan produk dengan mempertimbangkan suara konsumen (VoC) dan mengukur nilai investasi dari produk cairan pelapis permukaan air pada kloset. Tahap pertama yang dilakukan yaitu penentuan segmentasi pasar yaitu kalangan milenial yang berada di wilayah metropolitan. Tahap selanjutnya yaitu penyebaran kuisioner pendahulu terhadap target segmentasi, dan riset produk pewangi ruangan yang sudah beredar di pasaran. 
Penyebaran kuisoner pendahuluan dilakukan untuk mengetahui atribut apa saja yang akan muncul sebagai voice of customer. Di tahap ini, kuisioner dibagikan kepada 24 responsden yang sesuai dengan target segmentasi penelitian. Kuisioner pendahulu disajikan dalam bentuk isian dan berisi tentang hal-hal yang dirasa penting oleh konsumer untuk menjadi atribut produk dengan fungsi menghilangkan bau feses pada toilet. Dari hasil kuisioner pendahuluan, pendapat reponden dikelompokkan menjadi beberapa atribut utama. Pendapat konsumen mengenai atribut produk yang dianggap penting ini kemudian menghasilkan 5 atribut utama, yaitu aroma, desain, portabilitas, efektivitas, dan harga (Tabel 3). Atribut aroma dideskripsikan sebagai kewangian yang digunakan sesuai dengan keinginan konsumen. Atribut desain dideskripsikan sebagai seberapa menarik desain dan pengemasan yang digunakan oleh produk. Atribut portabilitas dideskripsikan sebagai seberapa ringan dan kecil ukuran untuk kemudahan membawa produk ke berbagai tempat setiap harinya. Atribut efektivitas dideskripsikan sebagai seberapa ampuh produk bekerja dalam menghilangkan bau dan ketahanan dari wanginya. Atribut harga dideskripsikan sebagai harga beli produk oleh konsumen yang terjangkau dengan mempertimbangkan harga produk kompetitor.

Langkah berikutnya adalah penyebaran kuisioner mengenai tingkat kepetingan masing-masing atribut menurut konsumen, dan persepsi mengenai performa dari produk pewangi toilet yang sudah beredar di pasaran. Kuisioner disajikan dalam skala likert dengan skala 1-5. Skala 1 menunjukkan sangat tidak penting dan skala 5 menunjukkan atribut sangat penting bagi konsumen. Hasil kuesioner merupakan input untuk pengerjaan QFD dalam membangun HOQ (House Of Quaity). Rekap atribut hasil kuisoner menjadi nilai importance to customer. Kemudian penelitian dilanjutkan dengan penentuan respons teknis, penyusunan matriks korelasi antara respons teknis dengan atribut kepentingan konsumen serta matrik korelasi antar respons teknis, dan penentuan prioritas spesifikasi atau target.

Penelitian dilanjutkan dengan melakukan uji kelayakan investasi bagi produk pengembangan dari pewangi toilet yaitu Hide My Poo. Hide My Poo merupakan produk pelapis permukaan air pada kloset sebagai penahan bau feses dan program wirausahanya sudah berjalan dari bulan Mei 2019 - Juni 2019. Uji kelayakan investasi dilakukan dengan menggunakan alat analisis laporan laba rugi, arus kas (cash flow), Metode Break Event Point (BEP), Metode Net Present Value (NPV), Metode Internal Rate of Return (IRR), Payback Period (PP), dan Profitability Index (PI).

\section{Hasil dan Pembahasan}

a. Quality Function Deployment (QFD)

Perancangan produk merupakan kegiatan yang penting dilakukan sebelum proses produksi berjalan, karena dalam tahapan perancangan produk akan diperoleh informasi detail dari benda yang akan dibuat (Ginting, 2009). Quality Function Deployment merupakan suatu pendekatan sistematik untuk mengetahui permintaan konsumen dan menerjemahkannya kedalam desain teknis, manufaktur dan perencanaan produksi yang tepat (Kwong \& Bai, 2002). Evaluasi produk untuk membandingkan antara produk eksisting yang menjadi kompetitor dengan produk yang dirancang yakni dengan melakukan benchmarking. Evaluation score merupakan penilaian dari produk eksisting atau produk yang sudah ada di pasaran yaitu pewangi ruangan spray. Target value adalah nilai yang diharapkan dari produk baru yang sedang dirancang atau dikembangkan.

Tujuan evaluasi produk adalah mendapatkan penilaian berupa pembobotan untuk mengetahui atribut-atribut mana sajakah yang dianggap paling penting dan harus diprioritaskan untuk memiliki performa yang baik dalam produk baru berdasar nilai bobot. Hasil penilaian menunjukkan bahwa atribut efektivitas memiliki prioritas pertama dengan nilai bobot $24.13 \%$. Sedangkan atribut prioritas kedua hingga terakhir yaitu portabilitas, harga, desain, dan aroma dengan masing-masing persen bobotnya yaitu $23.08 \%, \quad 21.51 \%, \quad 15.9 \%$, dan $15.39 \%$. Matriks interaksi merupakan tingkat relasi/hubungan antara atribut dengan respons teknis yang sudah dirumuskan (Tabel 4). Tingkat hubungan digolongkan atas tiga golongan yakni strong, medium, dan weak yang bernilai 9 (lingkaran hitam), 3 (lingkaran putih), dan 1 (segitiga). Tabel 4 merupakan matriks interaksi antara atribut dengan respons teknis.

Tabel 3. Respons Teknis terhadap Atribut Keinginan Konsumen

\begin{tabular}{ll}
\hline \multicolumn{1}{c}{ Atribut Keinginan Konsumen } & \multicolumn{1}{c}{ Respons Teknis } \\
\hline Aroma & Proporsi/Komposisi Bahan Baku \\
& Jenis Bahan Baku \\
Desain & Bahan Kemasan \\
& Desain Logo Kemasan \\
& Warna Kemasan \\
Portabilitas & Bahan Kemasan \\
& Ukuran Kemasan \\
Efektivitas & Proporsi/Komposisi Bahan Baku \\
Harga & Proporsi/Komposisi Bahan Baku \\
& Jenis Bahan Baku \\
& Bahan Kemasan \\
\hline
\end{tabular}


Tabel 4. Matriks Interaksi Atribut dengan Respons Teknis

\begin{tabular}{|c|c|c|c|c|c|c|c|}
\hline $\begin{array}{l}\text { Atribut Keinginan } \\
\text { Konsumen }\end{array}$ & $\begin{array}{c}\text { Proporsi/Komposisi } \\
\text { Bahan Baku }\end{array}$ & $\begin{array}{c}\text { Jenis Bahan } \\
\text { Baku }\end{array}$ & $\begin{array}{c}\text { Bahan } \\
\text { Kemasan }\end{array}$ & $\begin{array}{c}\text { Desain } \\
\text { Logo } \\
\text { Kemasan } \\
\end{array}$ & $\begin{array}{c}\text { Warna } \\
\text { Kemasan }\end{array}$ & $\begin{array}{l}\text { Ukuran } \\
\text { Kemasan }\end{array}$ & Weight \\
\hline \multirow[t]{2}{*}{ Aroma } & $\bullet$ & 0 & & & & & \\
\hline & 34.776 & 11.592 & 0 & 0 & 0 & 0 & 3.864 \\
\hline \multirow[t]{2}{*}{ Desain } & & & $\nabla$ & $\bullet$ & $\bullet$ & & \\
\hline & 0 & 0 & 4.704 & 42.336 & 42.336 & 0 & 4.704 \\
\hline \multirow[t]{2}{*}{ Portabilitas } & & & $\bullet$ & & & ○ & \\
\hline & 0 & 0 & 11.616 & 0 & 0 & 11.616 & 3.872 \\
\hline \multirow[t]{2}{*}{ Efektivitas } & $\bullet$ & $\circ$ & & & & $\nabla$ & \\
\hline & 34.884 & 11.628 & 0 & 0 & 0 & 3.876 & 3.876 \\
\hline \multirow[t]{2}{*}{ Harga } & o & & $\bullet$ & & & ○ & \\
\hline & 11.97 & 0 & 35.91 & 0 & 0 & 11.97 & 3.99 \\
\hline Total & 81.63 & 23.22 & 52.23 & 42.336 & 42.336 & 27.462 & 269.214 \\
\hline Prioritas & 30.32 & 8.63 & 19.40 & 15.73 & 15.73 & 10.20 & 100 \\
\hline
\end{tabular}

Atribut harga dengan bahan kemasan mempunyai tingkat relasi yang sangat kuat, karena biaya bahan baku kemasan berbanding lurus dengan harga produk. Ketika biaya kemasan kecil, maka produk dapat diluncurkan dengan harga yang rendah. Selain itu, atribut efektivitas juga memiliki hubungan yang kuat dengan komposisi bahan baku. Hal ini didasarkan bahwa komposisi bahan baku yang digunakan menentukan ketahanan aroma produk untuk menghilangkan bau tidak sedap. Atribut portabilitas juga memiliki hubungan yang kuat dengan bahan kemasan. Hal ini didasarkan pada bahan yang digunakan untuk kemasan agar tidak mengganggu portabilitas dari produk. Sehingga pelanggan tidak mengalami kesulitan dalam menggunakan produk. Tingkat relasi yang kuat juga terjadi pada atribut aroma dengan proporsi bahan baku. Pemilihan komposisi bahan baku alami dapat menghasilkan aroma yang lebih mudah diterima oleh pelanggan.

Pada matriks interaksi, terdapat hubungan yang lemah antara atribut desain dengan bahan kemasan, karena yang menjadi pertimbangan kuat bagi pelanggan dalam memilih desain adalah warna dan logo kemasan. Selain itu hubungan yang lemah juga terdapat pada atribut efektivitas dengan ukuran kemasan, di mana ukuran produk tidak menjamin keberhasilan produk menghilangkan bau tidak sedap. Pada perhitungan untuk penentuan prioritas, didapatkan bahwa respons teknis komposisi bahan baku merupakan hal yang diutamakan. Kemudian respons teknis bahan kemasan menjadi prioritas selanjutnya dan disusul dengan respons teknis desain logo, warna, dan ukuran kemasan serta jenis bahan baku.

\section{b. Analisis Kelayakan Investasi}

Kasmir dan Jakfar (2012) menyatakan bahwa analisis kelayakan investasi adalah kegiatan yang mempelajari secara mendalam tentang suatu kegiatan, usaha dan bisnis yang dijalankan. Sedangkan Husnan dan Suwarsono (2008) menyatakan bahwa analisis kelayakan investasi merupakan penelitian tentang dapat atau tidaknya suatu proyek investasi dilaksanakan dengan berhasil. Pengembangan produk dengan pendekatan QFD menghasilkan desain produk Hide My Poo yang merupakan cairan pelapis permukaan air pada kloset. Harga pokok penjualan untuk produk Hide My Poo adalah Rp 9.105,-Dengan harga jual Rp 20.000,- per botolnya, maka laba kotor tiap penjualan 1 botol Hide My Poo yaitu Rp 10.895,- atau keuntungan kotor sampai dengan $120 \%$ dari biaya produksi (Tabel 5).

Tabel 5. Perhitungan Harga Pokok Penjualan

\begin{tabular}{lr}
\hline \multicolumn{2}{c}{ Harga Penjualan Pokok } \\
\hline \multicolumn{1}{c}{ Item } & Biaya (Rp) \\
\hline Pembelian Material & 27.500 \\
Alkohol kadar 99\% & 1.225 .000 \\
Essential Oil & 2.050 .000 \\
Botol Plastik 60ml & 750.000 \\
Packaging & 500.000 \\
Biaya Tenaga Kerja & 4.552 .500 \\
Total Biaya Produksi & 9.105 \\
HPP per Unit & \\
\hline
\end{tabular}

Sumber: Tim pengembangan produk Hide My Poo, 2019

Pada pelaksanaan uji coba pasar diperoleh hasil penjualan produk seperti dijabarkan dalam Tabel 6 . Tabel 6 menunjukkan bahwa terjadi penurunan laba dari bulan Mei ke Juni dan kembali naik dari bulan Juni ke Juli. Pada bulan Mei, tidak dikeluarkan biaya untuk marketting sedangkan bulan Juni menghabiskan sampai dengan Rp 665.000,- untuk kebutuhan marketting. Biaya marketting turun pada bulan Juni ke Juli dari Rp 665.000,- menjadi Rp 340.000,-. Keuntungan yang lebih besar juga didapat karena kenaikan jumlah penjualan dari bulan Juni yang hanya 73 unit menjadi 92 unit pada bulan Juli. Dalam laporan laba rugi usaha "Hide My Poo" belum mempertimbangkan biaya pajak. 
Tabel 6. Analisis Laba Rugi

\begin{tabular}{lccc}
\hline \multicolumn{1}{c}{ Bulan } & Mei & Juni & Juli \\
\hline \multicolumn{1}{c}{ Jumlah Terjual (Unit) } & 21 & 73 & 92 \\
\hline Pemasukan & & & \\
Penjualan (Rp) & $420.000,-$ & $1.460 .000,-$ & $1.940 .000,-$ \\
Total Pemasukan (Rp) & $420.000,-$ & $1.460 .000,-$ & $1.940 .000,-$ \\
Pengeluaran & & & \\
Produksi (Rp) & $170.205,-$ & $531.65,-$ & $737.555,-$ \\
Marketing (Rp) & - & $665.000,-$ & $340.000,-$ \\
Total Beban (Rp) & $170.205,-$ & $1.256 .665,-$ & $1.077 .55,00$ \\
Laba/Rugi Bersih (Rp) & $249.795,-$ & $203.335,-$ & $862.445,-$ \\
\hline
\end{tabular}

Sumber: Tim pengembangan produk Hide My Poo, 2019

Perhitungan payback period pada Tabel 7 dengan asumsi penjualan dari periode ke-4 sampai dengan bulan ke-10 mencapai target penjualan sebanyak 100 unit perbulannya dan biaya yang dikeluarkan untuk promosi dan pemasaran sebesar $10 \%$ dari total penjualan. Berdasarkan data yang didapat, payback period dari Hide My Poo yaitu 8,63 bulan atau 8 bulan 19 hari.

Nilai Net Present Value dijabarkan dalam Tabel 8. Dengan menggunakan interest rate sebesar $1,1 \%$ per periode, didapatkan proyeksi $N P V$ untuk periode ke-10 (Februari 2020) sebesar Rp 10.612.209,-. Nilai cash inflow didapatkan dengan asumsi dari periode ke-4 sampai dengan ke-10 mencapai target penjualan sebesar 100 unit per bulannya. Dengan begitu, dapat dinyatakan layak pada bulan ke-5 karena NPV sudah berada lebih besar dari 0 .

Nilai Profitability index (PI) dijabarkan dalam Tabel 10. Dengan menggunakan interest rate sebesar $1,1 \%$ per periode, didapatkan proyeksi $P I$ sebesar 1,75 untuk periode ke-10 (September). PI ini didapat dari membandingkan net present value dengan investasi awal. Dengan begitu, dapat dinyatakan layak pada periode ke-10 karena $\mathrm{PI} \geq 1$.

Tabel 7. Payback Period

\begin{tabular}{ccc}
\hline $\begin{array}{c}\text { Periode } \\
\text { (Bulan) }\end{array}$ & $\begin{array}{c}\text { Laba Bersih } \\
(\mathrm{Rp} .)\end{array}$ & $\begin{array}{c}\text { Cash Balance } \\
(\mathrm{Rp} .)\end{array}$ \\
\hline 0 & $(6.080 .000)$ & - \\
1 & 228.795 & $(6.080 .000)$ \\
2 & 130.335 & $(5.720 .870)$ \\
3 & 716.815 & $(5.004 .055)$ \\
$4^{*}$ & 889.500 & $(4.114 .555)$ \\
$5^{*}$ & 889.500 & $(3.225 .055)$ \\
$6^{*}$ & 889.500 & $(2.335 .555$ \\
$7^{*}$ & 889.500 & $(1.446 .055)$ \\
$8^{*}$ & 889.500 & $(556.555)$ \\
$9^{*}$ & 889.500 & 332.945 \\
$10^{*}$ & 889.500 & 1.222 .445 \\
\multicolumn{2}{c}{ Payback Period } & 8,63 \\
\hline
\end{tabular}

*Asumsi mencapai target penjualan 100 unit per bulan

Nilai Internal Rate of Return dijabarkan dalam Tabel 9. Dengan menggunakan interest rate sebesar $1,1 \%$ per periode, didapatkan proyeksi IRR sebesar $22,32 \%$ untuk periode ke-10 (September). Dengan begitu, dapat dinyatakan layak pada bulan ke-10 karena IRR lebih besar dari interest rate yang berlaku.

Tabel 8. Net Present Value

\begin{tabular}{lrr}
\hline $\begin{array}{c}\text { Periode } \\
\text { (Bulan) }\end{array}$ & $\begin{array}{r}\text { Cash Inflow } \\
\text { (Rp.) }\end{array}$ & \multicolumn{1}{c}{ NPV (Rp.) } \\
\hline 0 (April) & -6.080 .000 & - \\
1 & 420.000 & -5.664 .570 \\
2 & 1.460 .000 & -4.236 .167 \\
3 & 1.940 .000 & -2.358 .804 \\
$4^{*}$ & 2.000 .000 & -444.437 \\
$5^{*}$ & 2.000 .000 & 1.449 .102 \\
$6^{*}$ & 2.000 .000 & 3.322 .039 \\
$7^{*}$ & 2.000 .000 & 5.174 .597 \\
$8^{*}$ & 2.000 .000 & 7.006 .999 \\
$9^{*}$ & 2.000 .000 & 8.819 .464 \\
$10^{*}$ & 2.000 .000 & 10.612 .209 \\
& & $\mathbf{1 0 . 6 1 2 . 2 0 9}$ \\
\hline
\end{tabular}

*Asumsi mencapai target penjualan 100 unit per bulan

Tabel 9. Internal Rate of Return

\begin{tabular}{ccc}
\hline Periode (Bulan) & Cash Inflow (Rp.) & NPV (Rp.) \\
\hline 0 (April) & -6.080 .000 & - \\
1 & 420.000 & -5.664 .570 \\
2 & 1.460 .000 & -4.236 .167 \\
3 & 1.940 .000 & -2.358 .804 \\
$4^{*}$ & 2.000 .000 & -444.437 \\
$5^{*}$ & 2.000 .000 & 1.449 .102 \\
$6^{*}$ & 2.000 .000 & 3.322 .039 \\
$7^{*}$ & 2.000 .000 & 5.174 .597 \\
$8^{*}$ & 2.000 .000 & 7.006 .999 \\
$9^{*}$ & 2.000 .000 & 8.819 .464 \\
$10^{*}$ & 2.000 .000 & 10.612 .209 \\
\multicolumn{4}{c}{ NPV } & 10.612 .209 \\
& IRR & $22,32 \%$ \\
\hline
\end{tabular}

*Asumsi mencapai target penjualan 100 unit per bulan Sumber: Hide My Poo, 2019

Metode payback period memiliki kelebihan yaitu cukup akurat untuk mengukur nilai investasi yang diperbandingkan untuk beberapa kasus dan bagi pembuat keputusan, sedangkan kelemahannya yaitu mengabaikan penerimaan-penerimaan investasi atau proceeds setelah payback period tercapai. Metode net present value memiliki kelebihan yaitu tidak mengabaikan aliran kas selama periode proyek atau investasi dan memperhatikan nilai waktu daripada 
uang, sedangkan kelemahannya yaitu lebih sulit penerapannya daripada payback period. Metode internal rate of return memiliki kelebihan yaitu mengutamakan aliran kas awal daripada aliran kas belakangan, sedangkan kelemahannya yaitu lebih sulit dalam melakukan perhitungan.

Tabel 10. Profitability Index

\begin{tabular}{|c|c|c|}
\hline $\begin{array}{l}\text { Periode } \\
\text { (Bulan) } \\
\end{array}$ & $\begin{array}{l}\text { Cash Inflow } \\
\text { (Rp.) }\end{array}$ & NPV (Rp.) \\
\hline 0 (April) & -6.080 .000 & - \\
\hline 1 & 420.000 & -5.664 .570 \\
\hline 2 & 1.460 .000 & -4.236 .167 \\
\hline 3 & 1.940 .000 & -2.358 .804 \\
\hline $4^{*}$ & 2.000 .000 & -444.437 \\
\hline $5^{*}$ & 2.000 .000 & 1.449 .102 \\
\hline $6^{*}$ & 2.000 .000 & 3.322 .039 \\
\hline $7 *$ & 2.000 .000 & 5.174 .597 \\
\hline $8^{*}$ & 2.000 .000 & 7.006 .999 \\
\hline $9 *$ & 2.000 .000 & 8.819 .464 \\
\hline $10 *$ & 2.000 .000 & 10.612 .209 \\
\hline \multicolumn{2}{|c|}{ PI } & 1,75 \\
\hline
\end{tabular}

*Asumsi mencapai target penjualan 100 unit per bulan

Metode profitibality index memiliki kelebihan konsisten dengan tujuan perusahaan, yaitu memaksimalkan kekayaan pemegang saham, sedangkan kelemahannya yaitu dapat memberikan panduan dan pilihan yang salah pada proyek-proyek yang mutually exclusive yang memiliki unsur ekonomis dan skala yang berbeda.

\section{Kesimpulan}

Perancangan dan pengembangan produk cairan pelapis permukaan air pada kloset diharapkan mampu memenuhi keingin konsumen. Dengan menggunakan pendekatan Quality Function Deployment yang menerjemahkan keinginan konsumen kedalam respons teknis, maka proporsi/komposisi bahan baku produk antara bahan-bahan alami dan kimia mejadi prioritas utama dalam perancangan dan pengembangan produk. Hal ini menentukan ketahanan produk dalam menahan bau tidak sedap yang berasal dari permukaan air pada kloset. Desain logo yang unik, warna yang menarik, dan ukuran yang memudahkan produk dibawa atau pun dipindahkan oleh pelanggan berkaitan dengan atribut desain yang terpenting bagi pelanggan. Selain itu jenis bahan baku berupa bahan alami juga menjadi kekuatan produk untuk menciptakan aroma yang mudah diterima oleh pelanggan. Dari aspek analisis kelayakan investasi, waktu yang dibutuhkan untuk menutup kembali pengeluaran investasi yaitu 8 bulan 19 hari. Sedangkan berdasarkan proyeksi NPV sebesar Rp 10.612.209 investasi dinyatakan layak pada bulan ke-5. Nilai IRR sebesar 22,32\% dan PI sebesar 1.75 menunjukkan bahwa investasi layak dilakukan. Strategi yang perlu diambil untuk meningkatkan analisis kelayakan investasi adalah dengan melihat aspek pemasaran.

\section{Daftar Pustaka}

Alexander, C. (1963). Notes on the Synthesis of Form. Cambridge: MA: Harvard Press.

Chisnall, P. (1979). Research for New Cosumer Products. European Reasearch, Vol. 7 No. 6, pp. 248-256.

Dede, M. F. (2007). Analisis Kelayakan Investasi untuk Rencana Perluasan Jaringan pada PT Telkom cabang Malang. Malang.

Fandri, A. R. (2005). Analisis Kelayakan Penambahan Mesin Untuk Meningkatkan Produksi pada PT Industri Kulit SURYA Magetan. Malang.

Gideon, H. (2007). Analisis Kelayakan Investasi Pengadaan Mesin Offset Separasi pada PT Patent Process. Jakarta.

Ginting, R. (2009). Perancangan Produk. Yogyakarta: Graha Ilmu.

Hartini, S. (2012). Peran Inovasi: Pengembangan Kualitas Produk dan Kinerja Pabrik. Jurnal Manajemen dan Kewirausahaan, Vol 14 No 1, halaman 82-88.

Husnan, \& Suwarsono, S. (2008). Studi Kelayakan Proyek. Yogyakarta: UPP AMP YKPN.

Kasmir, \& Jakfar. (2012). Studi Kelayakan Bisnis. Jakarta: Kencana.

Kotler, P. (2005). Manajemen Pemasaran. Jakarta: PT Indeks.

Kundu, C. K. (2010). Product Development : Concept and Reality. Sweden.

Kwong, C., \& Bai, H. (2002). A fuzzy approach to the determination of importance wights of customer requirements in quality function deployment. Journal of Intelligent Manufacturing, Vol 13, page 367-377.

Susanti, H. D. (2012). Analisis Kelayakan Investasi Perbaikan Sarana Produksi Pada Home Industri Kerupuk Bawang. Jurnal Teknik Industri $U M M$, Vol 13. No.1 pp 60-66.

Tandelilin, E. (2010). Portofolio dan Investasi Teori dan Aplikasi. Yogyakarta: Kanius.

Ulrich, K. T., \& Eppinger, S. D. (2000). Product Design and Development. New York: McGraw-Hill.

Umar, H. (2007). Studi Kelayakan Bisnis. Jakarta: Gramedia Pustaka Utama.

Utomo, C. (2017). Kajian Potensi Pengembangan Produk Transportasi Gyroplane. Surabaya.

White, R. (1976). Consumer Product Development. Penguin Books.

Wignjosoebroto, \& Sritomo. (2000). Evaluasi Ergonomis dalam Proses Perancangan Produk. Seminar Nasional Ergonomi. 